\title{
Delinking Multiliteracies and the Reimagining of Literacy Studies
}

\section{Desprendimento, multiletramentos e $o$ repensar dos estudos sobre letramento}

\author{
Ana Paula Martinez Duboc* \\ *Universidade de São Paulo (USP), São Paulo, São Paulo / Brasil \\ anaduboc@usp.br \\ https://orcid.org/0000-0002-3136-3504 \\ Lynn Mario Trindade Menezes de Souza** \\ **Universidade de São Paulo (USP), São Paulo, São Paulo / Brasil \\ lynnmario@gmail.com \\ https://orcid.org/0000-0001-8831-7034
}

\begin{abstract}
This paper proposes to critically read the multiliteracies proposal through a decolonial lens. It has two fundamental aspects: one, of an epistemic nature, refers to the need to de-link the concept from a particular hegemonic scholarship so that local knowledge production may prevent literacy practices from universalisms and methodologization; the other, of a technological nature, refers to the need to de-link the concept of multiliteracies from its apparent subjection to the digital.
\end{abstract}

KEYWORDS: delinking; decolonial; multiliteracies; diversity; local knowledges.

RESUMO: Este trabalho almeja uma leitura crítica, partindo das teorias decoloniais, da proposta original dos multiletramentos. A análise consiste de dois aspectos fundamentais; um, de natureza epistêmica, se refere à necessidade de afastar o conceito de multiletramentos de um uso hegemônico específico para que a produção de saberes locais possa inibir a universalização e a metodologização do conceito. O segundo aspecto, de natureza tecnológica, se refere à necessidade de destacar o conceito do efeito de parecer um quase sinônimo de letramentos digitais.

PALAVRAS-CHAVE: desprendimento; decolonial; multiletramentos; diversidade; conhecimentos locais. 


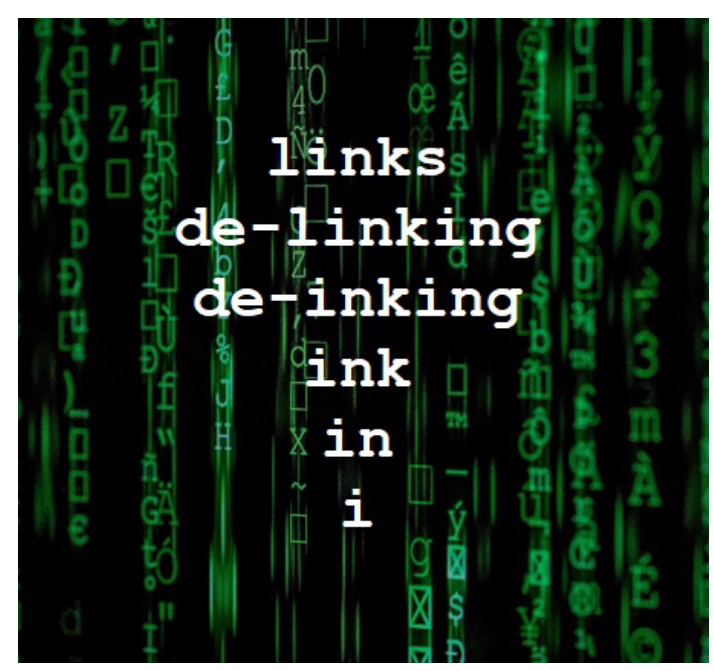

Elaborated by Ana Paula Duboc.

The epigraph that opens up this article is a concrete poem that I, Ana Duboc, presented during my talk in one of the Applied Linguistics Q\&A Sessions broadcast live on You'Tube ${ }^{1}$ in 2020 . The session, in particular, posed the following question to the invited speakers: "How can we promote critical education with multiliteracies?". Captured by my previous knowledge from my research on literacy studies over the past fifteen years and slightly bothered with the rapid emerging discourse on multiliteracies and digital technologies that sought to help teachers "adapt" to COVID-19 pandemic, I thought of giving up joining the session for I lacked a prompt answer.

I turned my computer off with that question in mind. It was dinner time. Then, bedtime. More precisely, bedtime reading with my then fiveyear-old daughter, Valentina. By that time, we had started reading Berimbau e outros poemas by Manuel Bandeira (2013) which soon became her favorite book. Night after night and Valentina would become familiar with Debussy, D. Janaina, O grilo, Vozes da noite, Irene no céu. Out of the many poems, she became fascinated with Porquinho-da-India. As I read the words - because

\footnotetext{
${ }^{1}$ The event was organized by Rosane Silveira (UFSC) and Alison Roberto Gonçalves (UFPR) and comprised a set of talks on Applied Linguistics. I, along with my colleague Alessandra Coutinho Fernandes (UFPR), was invited to the session on multiliteracies. Available at: https://youtu.be/VWGZttNf8ZU. Access on: Aug 24, 2020.
} 
mommy is able to "decode" that still awkward piece of alphabetic writing system to Valentina's eyes - she would hold the book, turn the page back and forth as she imagined extended narratives beyond what was out there, printed in her hands. One night, she grabs the book and tells me: "Sit here, I'll read poetry to you". Porquinho-da-india is her pick. And then she reads. Not reading in the sense of decoding - as the alphabet remains a bit awkward to her. Still, Valentina reads as she orchestrates a richly aesthetic literacy event (BARTON, 1994) by activating a rich variety of semiotic modes (KRESS, 2003) built over our bedtime reading. And while part of these modes is explicitly displayed at the printed book, what turns to be essential in her meaning making process is of an "invisible" kind to any interlocutor that is not part of our enunciation, a particular extra-discursive multisensorial experience which is located in time, in space, and mostly, in our situated bodies. As her mother, I easily recognize the echoing of my voice in her own and, most importantly, how my way of looking at her, cuddling her and smiling at her during our bedtime reading impacts her own way with words.

Voilá. Valentina's bedtime reading was the trigger to a set of questionings that came to my mind. I couldn't avoid the irony imbued in my recent findings as they somehow problematize previous stuff I myself have written. As a researcher, I could probably outline a talk on multiliteracies in relation to the digital turn. Or, I could refer to the pedagogy of multiliteracies in pandemic times. However, as a mother, I urged to talk about the highly emotional, bodily, tactile, visual and audio experience between my body and Valentina's for two reasons: i) such experience has nothing to do with digitality; still, it is pure multiliteracies; ii) such experience reminds me of how children seem to move easily between and across semiotic modes in their meaning making processes (BOCK, 2016; KRESS, 2003) without resorting to any a priori move; still, it might well inform how situated bodies play a central role in any pedagogy of multiliteracies.

The more I attempted to outline a response to the invited talk, the more I addressed questions that somehow put myself as a literacy researcher under a deep, critical scrutiny. Were I posed the same question some years ago, I would definitely answer differently and my epigraph-poem would not have even been created. However, as the interpretive processes in our coming to be (BIESTA, 2006) are highly affected by the theorizations we encounter, the experiences we live, the spaces we occupy, the bodies we meet and the tensions and ambiguities we face, the poem that opens this paper 
could only and did simply come to life by the hands of this white, upper middle-class woman, mother, lecturer and researcher facing social distancing with a young child at home in the midst of an endless pandemic.

Concrete poetry is usually characterized by a visual arrangement of linguistic elements whose graphic patterns turn to be of utmost relevance in interpretation. Marked by the green and black Matrix ${ }^{2}$-like background, ${ }^{3}$ the poem somehow reverberates the very virtual movement of the matrix, leading Western eyes to move from left to right and from top to bottom so that reading would start with the abundant pluralized form 'links", followed by an invitation towards a process of gradual detaching: firstly, the poem calls for detaching ourselves from the profusion of links - and likes - in digital social media specially in these pandemic times; then, it calls for detaching from the ink from our still highly-logocentric and cognitive society; finally, the poem wishes to move towards introspection, self-implication, subjectification, emotion, all imbued in the body of a minimalist "i $i$ ".

Needless to say, this is one out of many possible interpretations, what I want to pinpoint is that my poem is not an exquisite nor a highly creative piece of its kind. Nonetheless, my deliberate chosen typographical cues have been aesthetically displayed as an attempt to convey my recent viewpoints around the concept of multiliteracies. In other words, my poem wishes to synthetize my argument in favor of a reclaiming of multiliteracies as a social phenomenon under decolonial lenses and the reimagining of literacy studies, especially now in pandemic times. As context matters, I will begin with a very brief genealogical account on literacy studies. Then, attention will be driven to the very notion of multiliteracies, in particular, to the refracted and somehow metonymical understandings attributed to the term over the past years. By claiming that multiliteracies is old stuff (thus, not necessarily digital stuff), as well as it cannot be methodologized, I, then, argue in favor of delinking multiliteracies as we approach literacy theory and decoloniality. In line with Freire (1968 [2014]), to whom "no one can say the true word

\footnotetext{
${ }^{2}$ The Matrix is a 1999 American science-fiction movie which places humanity trapped inside a simulated reality (the Matrix, so to speak) which is controlled by intelligent machines. Directed by The Wachowskis and produced by Joel Silver (Warner Bros, Village Roadshow Pictures, Groucho II Film, Partnership, Silver Pictures).

${ }^{3}$ Photo "Hacker binary attack code" by Markus Spiske (1993) on Unsplash (https:// unsplash.com/).
} 
alone", I share these exploratory ideas with Lynn Mario wishing that our thoughts open up the terrain for further dialogue and reflection as Freire (1968 [2014], p. 109) once again states that "Dialogue is this encounter of men, mediated by the world, to pronounce it, never ending in the relation between I-you". 5

Literacy studies have long been marked by a tension between two major forces: on the one hand, a psychological and structuralist orientation to language that views literacy as an autonomous exercise (STREET, 1984); on the other, a sociocultural perspective to language that conceives of literacy as a social practice. In terms of pedagogical implications, whereas the former would focus on teacher-centered rote-memorization practices in which standardized language and canonic literature were privileged, the latter would focus on student-centered contextualized practices involving vernacular uses of language and oral tradition (DUBOC; FERRAZ, 2020; MONTE MÓR; DUBOC; FERRAZ, forthcoming).

The paradigm shift on literacy studies ${ }^{6}$ is usually tracked back in the 80 s with the seminal work of several scholars (BARTON, 1994; GEE, 2004, 2009; HEATH, 1983; STREET, 1984, 1995) whose language views were highly influenced by ethnographic-oriented Linguistic Anthropology. Nonetheless, the pioneering work of Paulo Freire back in the 1960s is undoubtedly a major pillar of the so-called New Literacy Studies (henceforth NLS) as his highly politically and ideologically driven notion of alfabetização would already encompass the notion of language as a social practice. That is why I couldn't agree more with the evolving literacy movement as well put by Monte Mór (2015) when the author decolonizes the very genealogy by locating Freire as the first generation on literacy studies, in which the contributions from the NLS turn out to be the second. Recent decades driven by globalization and the digital turn have brought a third generation to the fore in which scholars, particularly, Lankshear and Knobel (2003) in

\footnotetext{
${ }^{4}$ In the original "ninguém pode dizer a palavra verdadeira sozinho". Freire's notion of palavra verdadeira (true word) has no relation to universal truths, as he would conceive of the word as praxis (FREIRE, 1968 [2014], p. 107).

${ }^{5}$ In the original "O diálogo é este encontro dos homens, mediatizado pelo mundo, para pronuncia-lo, não se esgotando, portanto, na relação eu-tu”

${ }^{6}$ For a more detailed description of the evolving literacy movement, see Monte Mór, Duboc and Ferraz (forthcoming).
} 
their discussions on New Literacies as well as the New London Group (1994, 2000) with the Multiliteracies studies begun to enthusiastically approach literacy issues to the digital realm, in which emerging modes of living, working, knowing, and acting are acknowledged. For the purposes of this paper, it is precisely about the concept of multiliteracies that I want to share some of my recent thoughts.

The concept of Multiliteracies ${ }^{7}$ was first addressed by The New London Group in the 1990s in a seminal collective work brought by renown intellectuals who departed from a common ground concern, that is, to reshape the literacy theory and practice debate as they seemed to agree that educational outcomes turned out to fail towards a more democratic and just society. At that time, cultural and linguistic diversity was a key element and the group engaged in a debate on how to better address more inclusive literacy practices $v i s-\grave{a}-v i$ s the changing nature of work, citizenship and lifeworld. The group, then, coined the term Multiliteracies whose prefix multi would carry a two-folded meaning:

We decided that the outcomes of our discussions could be encapsulated in one word, 'Multiliteracies' - a word we chose because it describes two important arguments we might have with the emerging cultural, institutional, and global order. The first argument engages with the multiplicity of communications channels and media; the second with the increasing salience of cultural and linguistic diversity (COPE; KALANTZIS, 2000, p. 5).

In other words, influenced by multicultural studies and simultaneously attuned to the digital turn in the late 1990s, the group chose the prefix multi as a way to encompass both the need to expand representational settings as a way to acknowledge the visibility of different social and cultural contexts, as well as the need to expand communicational settings as a way to foster multimodal meaning making processes now made available by new digital technologies.

As for their original concern with literacy practices in educational contexts, the group framed what came to be widely known as "Pedagogy

\footnotetext{
${ }^{7}$ For a discussion on the different terminologies around literacy studies, see Kress (2003), Duboc (2015), Duboc and Gattolin (2015).
} 
of Multiliteracies" whose constitutive pedagogical dimensions comprise: (i) situated practice, that is, activities that bring in the students' own experiences and existing knowledge and immerse them in new experiences or information; (ii) overt instruction, that is, activities that get students to group and classify things, form concepts and define terms as well as to tie concepts together into generalizations; (iii) critical framing, that is, activities which explore cause, effects, relationships and functions as well as motives, purposes and interests; and (iv) transformed practice, that is, activities which require application of knowledge to actual problems and real world situations and, eventually, the transfer of knowledge to new situations and different contexts. ${ }^{8}$

The main argument of this paper is to reclaim the notion of multiliteracies as a social phenomenon and, in doing so, place the notion of social practice under scrutiny once again. When one retrieves the genesis of the New London Group's discussion around multiliteracies, one might find such claim unnecessary or obvious as the social and cultural element is out there. However, I believe its contextualized, social and cultural concern once stated along with their concern to prevent literacy theorizations from universalisms have possibly been sidestepped, blurred or even altered.

Consider the following visual literacy exploration, inspired by Andreotti's (2013) exercise in identifying then expanding the epistemic blindness within social imaginaries: if one types the Portuguese word "multiletramentos" on the Google images search device, visual representations range from book covers and Powerpoint slides to illustrations such as digital icons, computers, an interconnected globe, a multitasking man surrounded by "technological" gadgets, to name a few. Curiously, if one does the same exercise with the English word "multiliteracies", visual representations seem to be less related to digital icons and more related to theoretical and methodological issues raised by their founding scholars as the search leads us to prints of the well-known circular representation of the design elements and semiotic modes of meaning (THE NEW LONDON GROUP, 2000, p. 26), the four pedagogical dimensions as

\footnotetext{
${ }^{8}$ The pedagogy of multiliteracies has been widely used as a framework in academic work in Brazil and elsewhere. For a more detailed description, see the original work (THE NEW LONDON GROUP, 2000). For an extended version of these four pedagogical dimensions, see Kalantzis, Cope and the Learning by Design Group (2005). For local revisited and expanded versions of such pedagogy, see, for instance, Duboc (2015).
} 
originally addressed (THE NEW LONDON GROUP, 2000, p. 35) and its later expanded version (KALANTZIS; COPE; THE LEARNING BY DESIGN GROUP, 2005).

What lessons can be learned from my very preliminary visual literacy exercise in attempting to access the social imaginaries around the concept of multiliteracies?

Although the exercise seems to positively prove the Bakhtinian notion of language when he once claimed that "languages live a real life, they struggle and evolve in an environment of social heteroglossia" (BAKHTIN, 1981 [1975], p. 292), my concern refers to the two implications of certain refracted meanings to educational contexts: i) the word multiliteracies seems today strongly connected to digital technology to the extent of nearly having become synonyms (despite authors have acknowledged from the very beginning two dimensions of the multiplicity imbued in the prefix multi as discussed above); ii) the word multiliteracies seems to have been transformed into a universal and categorical methodological framework (despite authors have acknowledged from the very beginning the non-linear and non-fixed nature of the four pedagogical dimensions as described above).

In relation to the first implication, that is, the strong connection between multiliteracies and digital technologies, the new communication order fostered by digital media has, indeed, been rightly addressed as one of the facets of the multiliteracies studies with the "increasing multiplicity and integration of significant modes of meaning-making, where the textual is also related to the visual, the audio, the spatial, the behavioral, and so on." (COPE; KALANTZIS, 2000, p. 5-6). However, it has been nearly 25 years since the term was coined by The New London Group and I question: what has happened to the other facet promised in those earlier studies, that is to say, the acknowledgement of diverse sociocultural contexts whose local singularities would have to be accounted for in new literacy theory and practice? To what extent wouldn't the social facet become somehow blurred by the digital facet as a result of a kind of metonymical understanding of multiliteracies that has assumed the part as a whole, echoing a true, but incomplete view of the phenomenon? And most importantly, if social disparities were once the starting point of a fruitful discussion by a group of scholars who met in New London to discuss more inclusive literacy practices and considering that even greater inequality is now at stake during the COVID 19 pandemic, how can we, literacy scholars that speak from 
Freire's homeland, pay justice to his call for critique and change the terms of the conversation of our own literacy research and practice? As teachers, students, and families all over the world had to rapidly "adapt" to remote life and learning - instead of "questioning" or "problematizing" them where is our (self)critique in relation to neoliberal forces behind enthusiastic discourses of adaptation and collaboration (DUBOC, 2020)?

As for the second implication, that is, the fixity that ended up revolving around the methodological orientations within multiliteracies, I question myself to what extent the labelling "a pedagogy of multiliteracies" got into the traps of universalisms despite their discursive alerts. As precarization of teaching is a reality in many parts of the world, preventing teachers from elaborating their own pedagogical choices in relation to their local contexts, any pedagogical orientation runs the risk of becoming models or templates, so to speak. In this respect, I question: how can we, literacy scholars, along with literacy teachers, find ways to resist against ready-made agendas and struggle in favor of better working conditions so that agency and creativity are fostered?

Criticisms on the limits of the multiliteracies in Brazil (JORDÃO; MARSON; FRANCO, 2018; WINDLE; SILVA; MORAES; CABRAL, 2017, for instance) and elsewhere (MASNY; COLE, 2009; JACOBS, 2013; HUIJSER, 2006; LEANDER; BOLDT, 2012) have arisen in the last decades in relation to both the excessive centrality of the digital and the excessive centrality of framing.

In rereading multiliteracies, Leander and Boldt (2012, p. 29) suggest a rationalized orientation in still text-centric practices over the social and affective multiliterate dimension by claiming that "it is in the body that we locate the affective sensations of those registrations that are available to our consciousness, often making meaning of them by giving them form and significance as emotion, physical sensation, response, or energy."

In a similar vein, by proposing a multiple literacies theory under poststructuralist influence, Masny and Cole (2009, p. 5) claim that technological affordances have become excessively dominant within the multiliteracies theory which might hide the potentialities of what they call "primitive ways of working in literacy, to be found, for example, in the distribution of affect".

Harsher criticisms are posed by Jacobs (2013) to whom the concept of multiliteracies has become "reified and almost sacrosanct" (p. 270) within 
the literacy field. By claiming that "Multiliteracies, then, has become limited in how it describes the multiple aspects of literacies and instead has become almost synonymous with digital technology use and the use of popular media" (JACOBS, 2013, p. 271) - which corroborates the argument I am raising - the author advocates in favor of reimagining multiliteracies. In doing so, she proposes returning our attention to the original meaning of multi so that the notion of design is once again related to the spontaneous, random, and unexpected.

Corroborating Jacobs' concern with a supposedly overmethodologization, Huijser (2006) seems to suggest a contradiction within the multiliteracies as if the framework had become a teacher-centered toolkit despite the situated nature imbued in one of its four pedagogical orientations. By acknowledging out-of-school knowledges, the author claims that (2006, p. 27):

[t] here is too much emphasis in multiliteracies on what and how we need to teach students, and not enough on what different sets of skills students themselves bring to our classrooms. Despite the Situated Practice component, there is an implication that multiliteracies is something that needs to be taught, which in turn assumes that students do not already possess 'multimodal' abilities when they arrive in our classrooms.

How do criticisms have evolved in Brazil? Among several literacy scholars, it is worth to recall the Global South notion of gambiarra posed by Windle et al. (2017) as a clumsy alternative metaphor to the neat notion of design in which teachers work on what they have at hand in a process that might include non-high-tech affordances. No less thought-provoking is the book creatively organized by Jordão et al. (2018) in which the authors pay justice to what the book is all about: an urgent call for (self)critique. Through a set of made-up encounters between literacy scholars, the competing literacy views are provocatively displayed, leading readers to an interpretive and self-reflective journey on where we stand in relation to those views.

Criticisms on the limits of multiliteracies as discussed above corroborate my most recent exploratory ideas on the need to reclaim multiliteracies as a social phenomenon as the term might have been contaminated by metonymical understandings and deserve to be 
problematized specially in pandemic times. In doing so, two main premises come to my mind: multiliteracies is old stuff (which, in turn, leads to the notion that multiliteracies is not necessarily digital stuff) and multiliteracies cannot be methodologized.

In this respect, I seek support in the pioneering work of literacy scholars who have addressed issues of multiplicity long before the term multiliteracies was coined. What kind of multiplicity am I referring to? The kind that displays words and worlds kinesthetically in contextualized, meaningful moves, regardless of digitality. For the purposes of this paper, attention to the non-digital will be drawn. Take young Freire (1981), for instance, in his description of how he learned how to read and write:

Deciphering the word flowed naturally from reading my particular world; it was not something over it. I learned how to read and write on the ground of the backyard of my house, in the shade of the mango trees, with words from my world rather than from the wider world of my parents. The ground was my blackboard; sticks, my chalk (FREIRE, 1981, p. 15). ${ }^{9}$

Got the picture? Smelled the mango? Heard the scratching sound of the sticks while the small hands of Freire doodled something on the ground? Meet young Freire, entering the literacy world surrounded by what he possessed at hand in relation to resources, values, and relationships located in space and time, more precisely, Estrada do Encanamento, 724, Casa Amarela, Recife, Northeast, Brazil, ${ }^{10}$ back in the 1920s. No clicks, no links, no likes - at least not the type from digital societies which we are all familiar with. Still, multiliteracies is out there, as the young Freire undoubtedly experiences a multimodal, situated and meaningful multiliterate practice.

Moving on with my ethnographic lenses in relation to literacy practices - which makes me wonder to what extent ethnography itself hasn't been sidestepped in literacy scholarship and whether some revision at this issue is made necessary as well - I decide to retrieve another pioneering literacy scholar, Heath (1983), whose nine-year ethnographic study on

\footnotetext{
${ }^{9}$ In the original: "Fui alfabetizado no chão do quintal da minha casa, à sombra das mangueiras, com palavras do meu mundo e não do mundo maior dos meus pais. O chão foi meu quadro-negro, gravetos, o meu giz" (FREIRE, 1981, p. 16).

${ }^{10}$ Freire and Guimarães (2020).
} 
communication in two different working-class communities in South Carolina became a watershed in the area. And here I particularly recall Heath's concern with the multiple in communication when she (1983, p. 220) states that "patterns of interactions between oral and written uses of language are varied and complex, and the traditional oral-literate dichotomy does not capture the ways other cultural patterns in each community affect the uses of oral and written language." No wonder the author (HEATH, 1982) provides the reader with a very detailed description on the surrounding semiotic modes made present in the first year of one of the investigated community's baby:

$[\mathrm{H}]$ e spends most of his first year within this world of colorful, mechanical, musical, and literacy-based stimuli. He hears the nursery rhymes recited and referred to, and he is expected to come to know their association with characters, rhymes, and pictures in books. The things of his environment promote exploration of colors, shapes, and textures. He is fed in an infant seat with a row of colored balls across the front. His car seat has a mock steering wheel covered with vinyl or terry cloth. In his crib, he plays with a stuffed ball with sections of fabrics of different colors and textures, and his stuffed animals vary in texture, size, and shape (HEATH, 1983, p. 84).

The questioning posed by Heath (1983) on the conventional divide between the oral and the written along with her call to view literacy practices in their complexity echo the richness in multimodal communication dated centuries ago. In this respect, it might be worth to refer back to the kinesthetic and synergistic meaning making processes from non-Western societies, such as the Kaxinawa's multimodal writing (MENEZES DE SOUZA, 2003b) in Brazil and the plurilingual ethos that characterizes Indian and Pakistani society (KHUBCHANDANI, 1998).

In relation to the former, MENEZES DE SOUZA (2003b) states that Western logocentricity neglected the complex and kinesthetic meaning making processes in which emotions, gestures, taste, touch, smell, the visual and the audio are put aside. The divide between the oral and the written in western logocentric society is questioned by the acknowledgment of Kaxinawa's heterogenous semiotic interactions. Logocentric lenses read Kaxinawa's writing as deficient. However, their kinesthetics in meaning making processes carry a very complex cultural practice. 
As for the latter, by acknowledging the plurilingual ethos that characterizes India and Pakistan whose richness hasn't been fully grasped by still conventional Western linguistics, Khubchandani (1998) reclaims a substantive shift within language scholarship to take seriously "the fuzzy reality and transactive domains of language(s) as a 'live force' in the contemporary milieu, recognizing the fact the language remains in perpetual flux along with the usage just as the reality keeps changing" (KHUBCHANDANI, 1998, p. 31). The author goes on by stating that, if speech is a living phenomenon, then "communication activates nonlinguistic devices whose meaning can be explicated "only from the imperative of the context and communicative tasks" (KHUBCHANDANI, 1998, p. 7).

As one can see, the notions of multimodality and multiliteracies go beyond the spatial and temporal realms of contemporary Western-based multiliteracy studies leading me once again to get back to pioneering debates. Pratt (1999), for instance, back in the 1990s, addresses the importance of exploring multiple semiosis in writing and literacy in what she calls "contact zones" defined by her $(1999$, p. 2) as the "social spaces where cultures meet, clash, and grapple with each other, often in contexts of highly asymmetrical relations of power, such as colonialism, slavery, or their aftermaths as they are lived out in many parts of the world today.'By retrieving the complex multimodal, transcultural and pluri-versal manuscript Primer nueva corónica y buen gobierno (First new chronicle and good government) written by indigenous Andean Guamán Poma de Ayala (ca. 1616), Pratt (1999) invites us to think of pedagogical arts of the contact zone so that literacy practices would comprise a multifaceted set of:

$[S]$ torytelling and in identifying with the ideas, interests, histories, and attitudes of others; experiments in transculturation and collaborative work and in the arts of critique, parody, and comparison (including unseemly comparisons between elite and vernacular cultural forms); the redemption of the oral; ways for people to engage with suppressed aspects of history (including their own histories), ways to move into and out of rhetorics of authenticity; ground rules for communication across lines of difference and hierarchy that go beyond politeness but maintain mutual respect; a systematic approach to the all-important concept of cultural mediation (p. 9). 
Worth noting in Pratt's sensitive and sensible text is the fact that she retrieves Guaman Pola's manuscript to pose her argument. And that, to me, makes all difference, as she, along with Freire, was probably one of the few scholars to start approaching literacy and decoloniality. In this respect, one might ask: What's so innovative in Pratt's ways with words if art, storytelling and the like have long been listed as must-have items even amongst the most elementary socioconstructivist curriculum? What difference does that make if all these multiple semiosis are fully covered within the multiliteracies framework in a neatly and beautifully displayed circular visual representation drawn by The New London Group (2000) in which each design (visual, gestural, spatial, audio, linguistic) has its own constitutive elements?

My enthusiasm in getting back to authors like Pratt lies in the simple fact that as she advocates in favor of pedagogical arts of the contact zone, it seems to me that what matters most is the contact, the experience, the contextualized bodies that meet somewhere, sometime, somehow. Consequently, contact becomes the a priori element of any design element one could ever design! That being said, I nowadays tend to feel more instigated by the way pioneering scholars long ago had addressed multimodality in literacy practices as their ideas echo neither "balance" nor "prescription" in the use of semiotic modes in one's redesigned processes. That is pure transformed practice, isn't it? Not the kind of applying the appropriate semiotic mode, but simply using what one has at hand, digitally and non-digitally.

In addition to her holistic and artistic eyes, Pratt (1999) goes even further: as bodies differ (and so do cultures and loci of enunciation), clashes, tensions, contradictions, ambiguities and conflicts arise, making communication a complex social phenomenon. This makes me envision how exciting the literacy debate can become if addressed under a decolonial perspective as one of the most intriguing question in decolonial thought is to find ways for an ethical and genuine communication, not the kind that is still ingrained with notions like intelligibility and appropriateness and here I wonder: haven't the a priori set of semiotic modes within the multiliteracies framework become tools for an intelligible and appropriate dialogue, resonating a still conventional way of thinking communication? but the kind that acknowledges opacity (VERONELLI, 2016) and fracture (MIGNOLO, 2000) as constitutive elements in the encounter with the other. As Veronelli (2016, p. 417-418) states: 
Opacities need to be preserved and one is never sure of understanding them. One has to give-on-and-with because one's self-assertions are inevitably linked to a sensuous physical presence, to an active body. So what is important is not the circulation of ideas or political projects but how they resonate in the body - the body as a sort of acoustic box-so that one doesn't claim possession of a purer piece of truth but also doesn't erase the factors of time and place that coalesce as they do in the body and are informed by the immediacy and urgency of the political, linguistic, and social conditions.

Veronelli's quote, as well as all the previous discussion, echoes Menezes de Souza's most recent concern (2019) in his proposal of "bringing back the body". By departing from a decolonial perspective, the author brings a harsh criticism against the deliberate invisibility of the other established by the eyes of the Modern-European-white-heterosexual subject. The notion of colonial difference seems to be essential for understanding this invisibility. As defined by Mignolo (2009, p. 46),

The colonial difference operates by converting differences into values and establishing a hierarchy of human beings ontologically and epistemically. Ontologically, it is assumed that there are inferior human beings. Epistemically, it is assumed that inferior human beings are rational and aesthetically deficient.

The colonial difference goes hand in hand with the cartesian dualist subject, as body was neglected to the detriment of the supremacy of mind. Consequently, by pervasively classifying human beings under the concept of race, some being more valued than others under a supposedly biological structure (QUIJANO, 2005), Modernity found ways to "justify" exploitation, domination, subjugation, extermination as the ones occupying the other side of the abyssal line (SANTOS, 2007) lacked reason, being, thus, objectified. This egopolitics of knowledge along with its long-term epistemic racism (GROSFOGUEL, 2007) has to be questioned by a geo-body-politics of knowledge (MIGNOLO, 2000) as this problematizes who generates knowledge and where knowledge is generated and, in doing so, brings back the body. In Menezes de Souza's words (2019, p. 10-11): 
We have to bring the body back into this. How do we do this? By something very simple, a term we use in decolonial theory: the locus of enunciation, the space from which we speak. When we bring into account the space from which we speak, then we bring into account something which has been eliminated in academic discourse, which is the body. To speak from a space means you are speaking from a body located in space and time. When a body is located in space and time, a body has memory, a body has experience, a body has been exposed to history and the various conflicts of history. History has multiplicity, contradictions, etc. Bringing back the body into our pedagogies has come through in this project, not only in re-imagining but also in the use of creativity.

In view of these criticisms, decolonial thought wishes to question the hegemonic and linear history of paradigms and epistemes by departing "from a locus of enunciation that is not that of a particular author but of the Other who have been historically marginalized or ignored" (VERONELLI, 2015, p. 109), paying justice to the very notion of "bringing back the body". In doing so, decoloniality calls for a set of actions or strategies aimed at re-existence, resistance, and resurgence of those subjugated bodies over history. For the purposes of this paper, I want to call attention to one of these strategies: delinking. Delinking is related to the notion of geo-bodypolitics of knowledge which implies a shift in the geography of reason through the questioning of the coloniality of power (MIGNOLO, 2009, 2018). Strategically speaking, Mignolo $(2009,2018)$ advocates in favor of an epistemic disobedience, that is, the exercise of making noise in the wellestablished modes of knowing, followed by the exercise of delinking as a process in which we detach ourselves from the ties of Western-based ideas.

So, my proposal towards delinking multiliteracies carries a twofolded aspect: one, of an epistemic nature, refers to the need to detach the concept from a particular scholarship in which literacy local practices avoid universalisms and methodologization; the other, of a technological nature, refers to the need to detach the concept from its supposedly subjection to the digital stuff.

Endless inspiring and hesitating thoughts pop-up in my mind as I question myself how I can better establish connections between literacies and decoloniality. In other words, if I want to prove my argument in relation to the need to reclaim multiliteracies as a social phenomenon that 
i) is old stuff (hence, not necessarily digital stuff) and ii) goes beyond methodologized practices and if such exploratory ideas are based on the assumption that recent metonymical understandings have somehow naturalized the triad "multiliteracies-digitality-methodology", then, how, when, where, with whom to start such critique? Is there anybody out there to establish this opaque, complex communicative contact zone? Anyone interested in delinking multiliteracies? Lynn, do you copy?

Ana, I copy loud and clear. I agree that over the last decades multiliteracies has unfortunately almost become a synonym for digital literacies. And this has in fact distanced me personally from more direct work with multiliteracies-as-digital literacies. My long-standing interest in the issue of literacy (singular) is not represented in much of current research on multiliteracies with a digital bent. This is not only for the reasons you invoke above - the distancing of the social-as-diversity aspect of the "multi" from current work in the area focusing massively on the digital and the excessive "pedagogizing" or "methodizing" involved in many current takes on multiliteracies - but also because certain key aspects of multiliteracies, such as multimodality, are often portrayed as relating to the digital.

As you also mention, much of my early work in literacy focused on multimodality and synesthesia in indigenous literacies (MENEZES DE SOUZA, 2001, 2002, 2003a, 2003b) when both terms were still relatively uncommon in Applied Linguistics. The fact is that I was reading literacy at the time from a social-semiotic framework and not a linguistic or applied linguistic one. Semiotics, as I saw it then, aimed at pointing towards the semiotic complexity and wealth of elements of meaning-making without attempting to reduce these elements to closed systems. This latter aim may be an inheritance from saussurean linguistics in its attempts to identify underlying structural systems in the complexities of apparently chaotic practice.

For me, multimodality, then, did not mean just the interaction of the textual with the imagetic, as it is often now taken to mean in multiliteracies; it then meant looking at bodies, human or non-human, which served as the supports of signs or as signs themselves. It looked at non-alphabetic forms of writing in which the appearance of written signs was metonymically connected to phenomena, such as visions and dreams, in cultures in which visions were not only valid as texts but also as sources of knowledge. Curiously, in retrospect, my work then did indeed look at virtual images, 
when virtual did not mean just digital but also included dreams or visions brought on by ritualistic practices of ayahuasca.

What I believe may be difficult to perceive in the current concept of multiliteracies is the singularity of the concept of literacy-in-the-singular referring to a complex notion of the relationship between signs (marks, inscriptions, tattoos, weavings) taken as 'writing' in specific local contexts, where 'writing' broadly signifies registering information on a particular support or surface, and where this register may not be necessarily alphabetic or material. This of course implied that writing here was entangled with other, non-logocentric, non-phonocentric and non-graphocentric epistemologies, in which 'writing' did not represent sound and did not refer to the vocal representation of meaning. This refers to Derrida's (1976) critique of the predominant Western notion of writing seen as a second-order representation of speech, which was held to be the primary representation of meaning, allegedly located in the mind. In the culture I looked at, meaning was not accessed through speech but through vision - in dreams or visions; hence, writing as the registration of meaning was done in graphic figurative or abstract drawings and not through the alphabet.

The multi- of the original project of multiliteracies lies in the rich contextual variation involved in each embodied or situated relationship between signs and meaning in various communities. For me, this meant that the phenomenon of literacy as a socio-cultural connection between signs and practices of reading and writing was always singular and abstract; its situated manifestations in each community or culture were varied and multiple. This begs the question of what is involved when the phenomenon (literacy) as well as the situated practices are pluralized (literacies). Do we see literacy in its singularity as a singular stable phenomenon which is merely manifested differently in different contexts? Or do we see the singular concept of literacy not as singular in the sense of a fixed stable semiotic process but as a semiotic onto-epistemological process which is complex, open and dynamic? In order to answer these questions, we have to consider issues of coloniality (MIGNOLO, 2009) and also of diversity and how these two interconnect. This may give us an insight into possible reasons why the original concern of multiliteracies with social diversity (COPE; KALANTZIS, 2000) has been almost forgotten.

Firstly, it is important to situate my reading of possible reasons as located within the colonized space of a university and an education 
located in the global south, until recently accustomed to unquestioningly accept the onto-epistemological knowledges of the global north and their presupposed norms. Having had access to postcolonial and decolonial theories and analyses, I have come to question myself as a colonized subject or an internally colonized subject (CUSICANQUI, 2020) constituted epistemically and ontologically by the discourses of the Global North which until recently resulted in the normalizing of my thinking as a subject of the Global North, in spite of being simultaneously traversed by discourses of the colonized Global South; the coloniality or internal colonization of this process led me until recently to submerge the discourses that constituted me and which did not comply with the hegemonic discourses of the Global North. I have already mentioned one example of such discourses, that literacy is primarily alphabetic and phonocentric; implicit in this is that it is the hegemonic knowledge of the Global North that possesses greater value. Also implicit in this is the onto-aspect of onto-epistemic that I mentioned earlier. As you mentioned, Ana Paula, Mignolo reminds us of the colonial difference that converts "differences into values [and] establishing a hierarchy of human beings ontologically and epistemically". The effect of this, also the result of internal colonization, was for us as academics of the Global South to see ourselves as less capable of producing knowledge and to therefore unquestioningly consume knowledge of the Global North and apply it, often uncritically.

In the leaving behind of considerations of diversity in the multi-, we have largely left ourselves and our situatedness behind as well. But there are two sides to this story. We have already mentioned coloniality and the colonial difference which has largely impeded us from considering our own processes of intellectual subjugation by naturalizing these processes, absorbing coloniality, and suffocating our very own difference as diversity. On the other side there is the often nominal treatment of diversity in the Global North as part of a process of inclusion which is merely additive and not deconstructive: there are those who are seen as 'diverse' and those who are seen as 'normal citizens'; once again the colonial difference at work. In such contexts, policies were made to 'absorb' the diverse into the fold of 'normal citizens', however, without challenging or transforming the logic that initially separated the 'normal' from the 'diverse'. Diversity then results in assimilation, a process that cleanses the characteristics that separate the 'diverse' from the 
'normal'; in other words, this understanding of opening up to diversity is in fact a process of homogenization of difference traversed by coloniality. ${ }^{11}$

Located on the colonized or 'wrong' side of colonial difference, Ahmed (2012) describes how, in her work to introduce diversity in institutions, she comes across contradictions between clear institutional policies for diversity and the practical reluctance and obstacles to diversity in these same institutions. She describes diversity work as similar to encountering walls and bringing these walls to the surface. She describes these walls as theoretical, discursive and perceptive constructs that are problematic constructs both for those who are kept out as much as for those who constructed them as walls and now want to do away with them. For both parties, she says a wall "is that which you do not get over. It is not over if you don't get over it" (p. 180). For the excluded, the wall is an almost physical obstacle that does not allow them access. For the dominant who once did the excluding and now want to include, the difficulty is to first get over (in the sense of deconstruct or abandon) the theoretical, discursive and perceptive constructs they initially constructed to exclude. Ahmed portrays these walls as political and ideological "blockages of thought" that inhibit the free flow of critical thought. Diversity cannot then just be decreed. Given that the blockages that first created the walls of exclusion also produced their invisibility, the process of construction of both these aspects needs to be the object of critique and transformed in order for the walls to recede and diversity to be appreciated and welcome. Ahmed's analysis of the institutional treatment of diversity makes clear the relationality and entanglement between those that exclude and those that are excluded.

Ranciére (1999) describes politics as arising from a count of the parts that are considered to constitute a community; he describes this count as false and a miscount in which for those that do the counting and count themselves as countable, there are always those that do not count, and are therefore invisible to those that do the counting. Thus, for Ranciére:

Politics exists because those who have no right to be counted as speaking beings make themselves of some account, setting up a community by the fact of placing in common

\footnotetext{
${ }^{11}$ For a longer discussion of this see Walsh (2012) on the distinction between interculturality and critical interculturality,
} 
a wrong that is nothing more than this very confrontation, the contradiction of two worlds in a single world: the world where they are and the world where they are not, the world where there is something "between" them and those who do not acknowledge them as speaking beings who count and the world where there is nothing (RANCIÉRE, 1999, p. 27).

Decolonial and Southern Theory take up a similar notion of the invisibility of the uncounted in the colonial difference. The decolonial strategy of delinking or disobedience follows a similar path to that pointed to by Ranciére: the setting up of a community which has as its common object the confrontation of the two worlds (the colonizing and the colonized), one of which (the colonized) has been made invisible.

Here, Ana Paula, is where my concern that you mentioned above, of "bringing the body back into the picture" acquires importance. Coloniality gave importance to bodies in different, contrasting ways connected to varying concepts of (in)visibility: it denied equality to the colonized body and its knowledges, negating their very existence (SANTOS 2007); at the same time it universalized the knowledges produced by white, male, Christian, heterosexual, rational, colonizing subjects by hiding (making invisible not as non-existent but as not-to-be-seen) the bodies of these subjects and therefore hiding their loci of enunciation and the situated local nature of these knowledges. These knowledges thus became 'universal' because they did not apparently emanate from any specific locality; they were considered fully-fledged "epistemologies". Meanwhile, where some colonized knowledges were taken into consideration, in spite of the invisibility (as non-existence) attributed to the bodies of the subjects that produced them, these knowledges could never aspire to being epistemologies or universal; they could only have local, restricted, folkloric value. In relation to literacy and written texts, for example, there was literature, universal, canonic on the one hand, and Indian literature or African literature on the other hand. "Bringing the body back" involves de-universalizing colonial knowledges, portraying them as also emanating from social and historic subjects located in specific geographical spaces with specific histories. Given that bodies occupy specific spaces and are the products and producers of specific histories, this strategy involves always attributing to subjects their loci of enunciation and always pointing to the loci of enunciation of the subjects that produced the knowledge one has in hand. 
A further aspect of bringing the body back is the role of affect. As you say, Ana, the reification of multiliteracies as digital literacy has indeed given little space to the role of affect in "primitive" literacy, where foundational literacy events often consisted of affect-laden parent-child reading or collective reading in some communities as portrayed by Heath (1983). It is Ranciére that explains the connection between affect and politics when he tells us that affects as sensibilities are distributed in different ways in different political systems. Authoritative political systems impose one particular form of sensibility, for example, objectivity or rationality as an absence or denial of affect. In contrast, a political system that recognizes a wide distribution of affects or sensibilities is defined as politically esthetic.

For Ranciére, politics, like art, is founded on an esthetic basis and can only be democratic when it allows a multiplicity of affects to be distributed in a given community. Ranciére's concept of a police politics which authoritatively enforces a particular and restricted distribution of affect is not unlike the concepts of coloniality of being and of knowledge (MIGNOLO, 2000, 2009) and the abyssal line (SANTOS, 2007) where colonial rationality and modern scientific subject were valued over other forms of being, thinking and feeling. The coloniality of Multiliteracies lies in its privileging of certain forms of knowledge over others where affect plays a minor role. In the indigenous literacy practices that I wrote about (MENEZES DE SOUZA, 2001, 2002, 2003a), knowledge was acquired through vision; here bodies and affects played a significant role. Firstly, in order to partake in the ayahuasca ritual, one must belong affectively to the community. This involves the almost pan-indigenous concept of "all our relations": outsiders must be considered as "parentes", real or metaphorical relatives, in order to be able to participate in the ritual, to consume ayahuasca and have access to a vision. Secondly, the vision itself occurs through the bodily absorption and interaction with ayahuasca. There is no 'universal' reaction to ayahuasca. One's vision and one's reaction to it are bodily and individual depending on factors such as diet and emotional condition.

In our alphabetic literacy practices traversed by coloniality and claims to universality, we would rarely admit that our access to and processing of knowledge is affected by our emotional and dietary conditions. It is these bodily aspects of indigenous knowledge that often make them vulnerable to claims that such knowledge is "subjective" and of little value as knowledge; as if there is any knowledge that doesn't emanate from or is not mediated 
by a subject, human or otherwise. Again, it is a case, in Ranciére's terms, of conflicting politics of esthetics and conflicting distributions of the sensible, some more marked by coloniality than others. Affect and empathy also make their absence felt in the learning of literacy practices such as academic presentations, teaching and debating. Even within literacy practices that value the social, a traditional literacy focus can often be found to persist, such that communication is still seen to be the mere transmission and reception of messages. We have come a long way past this, but this model of communication still resurfaces in academic presentations and in many teachers' manners of teaching where the lack of awareness of the importance of maintaining an affective, empathetic connection with one's listener is paramount. In such cases speakers and their listeners appear to become body-less, words and content come to the fore, but the result may often be bodily and negative - tediousness and fatigue. Moving beyond affect and the body, the decolonial strategy of localizing knowledge is not to be understood as an inversion of the colonial strategy of universalization. If it were, rather than putting an end to the walls that once excluded us, we would be maintaining the walls and simply exchanging places with those on the other side. A consideration of diversity would not be possible. Our critique of those with difficulties in dealing with diversity would be a farce.

As Cusicanqui (2020, p. 66) says, we need to see decolonization as a process in which we see ourselves both as "producers of knowledge and as interlocutors who can have discussions as equals" with other centers of thought and academic production in the world. We should reject processes of acculturation and assimilation, accept our double, and often contentious, inheritance of colonial and local knowledges and develop dialogic forms for the construction of knowledge. This is not an appeal to hybridity as convergence and the production of something mixed, the end-product of a process of intermingling. Cusicanqui proposes instead the metaphor of ch'ixi-an approximation of disparate elements which mutually affect each other in a never-ending relational dynamic process without ever becoming a finished end-product where one of the elements can be reduced to another.

Yes, Ana, we need to delink from the coloniality of a hegemonic interpretation of multiliteracies as digital literacy and as a question of new epistemologies pertaining to the digital. The coloniality of such a posture lies not only in privileging or reifying the digital, but also in accepting 'epistemologies' as universal with little critical appraisal of the loci of enunciation of the 
bodies of the subjects that produce and describe these epistemologies and their universal affordances. One result of not considering the ontoepistemological effect of digital literacies has been pointed to recently by the Brazilian press: the myth of universal digital access in Brazil (EDUCAMAISBRASIL, 2020; TOLEDO, 2020) hides the tragic fact that $42 \%$ of candidates for the public ENEM exam ${ }^{12}$ do not have digital access at home, a factor that could reflect negatively on their performance. Why is this onto-epistemological? If one considers that IBGE (PNAD, 2019) ${ }^{13}$ data shows that $56.10 \%$ of the Brazilian population identifies as black, and given that poverty and race co-relate in Brazil (OSORIO, 2019), the coloniality present in pushing for universal digital public exams in Brazil could well result in the continuing exclusion of Brazilians of a particular race and social class.

Rezende (2018), in contrast, more advanced in her decolonial delinking, does significant work in intercultural literacies, which she sees as onto-epistemological. Her focus is on rural knowledges and indigenous knowledges and their complex, unusual forms of non-alphabetic literacy questioning universalized presuppositions, such as those that attribute the capacity to produce and communicate knowledge only to human subjects (As she says, "waterfalls do speak"). ${ }^{14}$

The Makuxi artist, writer and thinker Jaider Esbell (ESBELL, 2021, ESBELL et al., 2019) also produces innovative decolonial multi-media and multimodal work interconnecting the visual with the oral knowledges of his community. An interesting example is the collectively authored text in the form of a play-script for the theatre (which was produced as a text post facto), from a recording of a collective performance/recital of a collectively agreed upon re-reading of Mario de Andrade's Macunaima; this in turn was a re-reading of indigenous myths collected by the German anthropologist

\footnotetext{
${ }^{12}$ ENEM, which is acronym for Exame Nacional do Ensino Médio (High School National Exam), is a non-compulsory, standardized exam that tests the level of knowledge of the high school students in Brazil. It has become an entrance exam for High Education institutions. ${ }^{13}$ PNAD, which stands for Pesquisa Nacional por Amostra a Domicílo, is the National Household Sample Survey annually conducted by IBGE (Instituto Brasileiro de Geografia e Estatística) with the purpose of gathering general characteristics of the population, education, labor, income and housing having the household as its unit of survey.

${ }^{14}$ In the original, "as cachoeiras falam".
} 
Theodor Koch-Grunberg. The decoloniality of the proposal lies also in its strong emphasis on dialogic, collective knowledge production as an antidote to universality. Apart from Esbell, three other indigenous subjects (with direct connections to the informant-sources of Koch-Grunberg in the early $20^{\text {th }}$ century) were active participants in the production of the cinematic presentation-oral performance-written text. Adding to the collectively authored multimodality involved, Esbell illustrates the written text with his visual art, not representing but narrating knowledges from his community in visual dialogue with the text. The text counterposes oral indigenous knowledges (seen by hegemonic Brazilian culture as 'myths') and written/filmed canonic knowledges, to challenge Andrade's Macunaima, the 'founding myth' of Brazilian culture. The challenge occurs by blurring the distinctions between the universal and the local, confronting hegemonic normalized white bodies with previously invisibilized, now marked and present, indigenous bodies, and by confronting standard literary written Portuguese with oral, regional indigenous Portuguese.

The vague and indirect references to the indigenous knowledges in Andrade's text are put in check by the presence of indigenous bodies that are now vociferous (ESBELL et al, 2019, p. 92-99):

Mario lê Macunaima de Mario de Andrade. Passam-se na tela trechos do filme Macunaima de Joaquim Pedro de Andrade. No fim, todos batem palmas. Jaider grita: Plágio!

Like the indigenous voices in Esbell et al. (2019), I join you, Ana Paula, in reiterating that we need to delink from the coloniality of hegemonic interpretations of multiliteracies and look at the various and interesting literacy practices around us that co-exist with our digital world. Once again, delinking is not a case of inverting the hegemony or restricting work on digital literacy. It simply appeals to the original project of valuing social diversity and the need to examine and understand how new or traditional, erudite or popular literacy practices dialogue with and transform the concept of literacy. More fundamentally, our effort at calling for a decolonial delinking is an appeal for the constant consideration of the political aspects of literacy, not only in terms of the themes and contents that we read, write and teach, but also in how we conceive of literacy. Over a quarter of a century after Brian Street's description of literacy practices as ideological became 
common sense, it may be time to go back to Freire's constant reminder of how intellectually and politically limiting common sense can be.

\section{Authors' contributions}

Ana Paula Duboc contributed to this text by writing pages 2-16 whereas Lynn Mario Menezes de Souza wrote the abstract and pages 16-25. Both were responsible for organizing the cited work.

\section{References}

AHMED, S. On Being Included: Racism and Diversity in Institutional Life. Durham: Duke University Press, 2012. DOI: https://doi.org/10.1215/9780822395324

ANDREOTTI, V. Conhecimento, escolarização, currículo e a vontade de "endireitar" a sociedade através da educação. Revista Teias, Rio de Janeiro, v.14, n. 33, p. 215-227, 2013.

BAKHTIN, M. M. The Dialogic Imagination: Four Essays. Austin; London: University of Texas Press, [1975] 1981.

BANDEIRA, M. Berimbau e outros poemas. Seleção José Elias. Ilustração Graça Lima. São Paulo: Global, 2013.

BARTON, D. An Introduction to the Ecology of Written Language. United Kingdom: Blackwell Publishers, 1994.

BARTON, D.; HAMILTON, M. Literacy Practices. In: BARTON, D.; HAMILTON, M.; IVANIČ, R. (ed.). Situated Literacies. London: Routledge, 2000. p. 7-15.

BIESTA, G. Beyond Learning: Democratic Education for a Human Future. London: Paradigm Publishers, 2006.

BOCK, Z. Multimodality, Creativity and Children's Meaning-Making: Drawings, writings, imaginings. Stellenbosch Papers in Linguistics Plus, Stellenbosch, ZA, v. 49, p. 1-21, 2016. Access on: 28 Jan. 2021. DOI: https://doi.org/10.5842/49-0-669

COPE, B.; KALANTZIS, M. (ed.). Multiliteracies: Literacy Learning and the Design of Social Futures. London: Routledge, 2000.

CUSICANQUI, S.R. Ch'ixinakax utxiwa: On Practices and Discourses of Decolonization. Cambridge: Polity Press, 2020. DOI: https://doi. org/10.4135/9781526492692.n20

DERRIDA, J. Of Grammatology. Baltimore: Johns Hopkins University Press, 1976. 
DUBOC, A. P. Do tecido da vida, do puído do vírus: sobre crianças, novelos e linhas. Revista X, Curitiba, v. 15, n. 4, p. 126-131, 2020. DOI: https://doi. org/10.5380/rvx.v15i4.76346

DUBOC, A. P. Atitude Curricular: Letramentos Críticos Nas Brechas Da Sala De Aula De línguas estrangeiras. Jundiaí: Paco Editorial, 2015.

DUBOC, A. P.; FERRAZ, D. M. What's Behind a Literacy War? A Discursive and Political Analysis of the Neoconservative Brazilian Literacy Policy. Journal of Multicultural Discourses, [S.l.], v. 15, n. 4, p. 436-457, 2020. DOI: https://doi.org/1 $0.1080 / 17447143.2020 .1800714$

DUBOC, A. P. M.; GATTOLIN, S. R. B. Letramentos e línguas estrangeiras: definições, desafios e possibilidades em curso. In: FERRARETO, R.; LUCAS, P. O. (org.). Temas e rumos nas pesquisas em Linguística (Aplicada): Questões empíricas, éticas e práticas. Campinas: Pontes, 2015. p.245-280.

EDUCAMAISBRASIL. Inclusão digital não existe para 4,8 milhões de estudantes no Brasil. Educamaisbrasil, [S.l.], 2020. Available at: https://www.educamaisbrasil. com.br/educacao/noticias/inclusao-digital-nao-existe-para-48-milhoes-deestudantes-no-brasil Access on: 28 jan 2021.

ESBELL, J. et al. Makunaimã: o mito através do tempo. São Paulo: Elefante Editora, 2019.

ESBELL, J. Sobre o artista. Galeria Jaider Esbell, [s/d.]. Available at: http://www. jaideresbell.com.br/site/sobre-o-artista/. Access on: 28 Jan. 2021.

FREIRE, P. A importância do ato de ler. 5. ed. São Paulo: Cortez, 1981.

FREIRE, P. Pedagogia do oprimido. 57. ed. Rio de Janeiro: Paz e Terra, [2014] 1968.

FREIRE, P.; GUIMARAES, S. Partir da infância: diálogos sobre educação. 2. ed. Rio de Janeiro: Paz e Terra, 2020.

GEE, J. P. A Situated-Sociocultural Approach to Literacy and Technology. In: BAKER, E. A (ed.). The New Literacies. Multiple Perspectives on Research and Practice. New York: The Guilford Press, 2010. p. 165-193.

GEE, J. P. Situated Language and Learning: A Critique of Traditional Schooling. United Kingdom: Routledge, 2004.

GROSFOGUEL, R. Descolonizando los universalismos occidentales: el pluriversalismo transmoderno decolonial desde Aimé Césaire hasta los zapatistas. In: CASTRO-GOMEZ, S.; GROSFOGUEL R. (ed.). Elgiro descolonial: Reflexiones para una diversidad epistémica más allá del capitalismo global. Bogotá: Siglo del Hombre Editores; Universidad Central, Instituto de Estudios Sociales Contemporáneos y Pontificia Universidad Javeriana, Instituto Pensar, 2007. p. 63-77. 
HEATH, S. B. Ways with Words: Language, Life, and Work in Communities and Classrooms. New York: Cambridge University Press, 1983. DOI: https://doi. org/10.1017/CBO9780511841057

HUIJSER, H. Refocusing Multiliteracies for the Net Generation. International Journal of Pedagogies and Learning, [S.l.], v. 2, n. 1, p. 21-33, 2006. DOI: https://doi. org/10.5172/ijpl.2.1.22

JACOBS, G. E. Reimagining Multiliteracies: A Response to Leander and Boldt. Journal of Adolescent \& Adult Literacy, [S.l.], v. 57, n. 4, p. 270-273, 2013. DOI: https://doi.org/10.1002/jaal.249

JORDÃO, C.; MARSON, I. C. V.; FRANCO, Z. (org.). Devaneios em atas: distopias teóricas nos multiletramentos e inglês como língua franca. Campinas: Pontes, 2018.

KALANTZIS, M.; COPE, B.; THE LEARNING BY DESIGN GROUP. Learning by Design. Melbourne: Common Ground Publishing Pty, 2005.

KHUBCHANDANI, L. M. Plurilingual ethos: A Peep into the Sociology of Language. Indian Journal of Applied Linguistics, [S.l.], v. 24, n.1, p. 5-37, 1998.

KRESS, G. Literacy in the New Media Age. London: Routledge, 2003. DOI: https:/ / doi.org/10.4324/9780203299234

LANKSHEAR, C.; KNOBEL, M. New Literacies: changing Knowledge and Classroom Learning. United Kingdom: Open University Press, 2003.

LEANDER, K.; BOLDT, G. Rereading "A Pedagogy of Multiliteracies": Bodies, Texts, and Emergence. Journal of Literacy Research, [S.l.], v. 45. n. 1, p. 22-46, 2012. DOI: https://doi.org/10.1177/1086296X12468587

MASNY, D.; COLE, D. R. Introduction to Multiple Literacies Theory: A Deleuzian Perspective. In: (ed.). Multiple Literacies Theory: A Deleuzian Perspective. The Netherlands: Sense Publishers, 2009. p. 1-11. DOI: https://doi. org/10.1163/9789087909116

MENEZES DE SOUZA, L. M. T. Decolonial Pedagogies, Multilingualism and Literacies. Multilingual Margins, Western Cape, ZA, v. 6, n. 1, p. 9-13, 2019. DOI: https://doi.org/10.14426/mm.v6i1.135

MENEZES DE SOUZA, L. M. T. Literacy and Dreamspace: Multimodal Texts in a Brazilian Indigenous Community. In: GOODMAN, S. et al. (org.). Language, Literacy and Education: A Reader. Stoke-on-Trent: The Open University, 2003a. p. 221-230. MENEZES DE SOUZA, L. M. T. Voices on Paper: Multimodal Texts and Indigenous Literacy in Brazil. Social Semiotics, [S.l.], v. 13, n. 1, p. 29-42, 2003b. DOI: https://doi.org/10.1080/1035033032000133508 
MENEZES DE SOUZA, L. M. T. As visões da Anaconda: a narrativa escrita indígena no Brasil, Semear, v.7, 2002, p. 223-237.

MENEZES DE SOUZA, L. M. T. Para uma ecologia da escrita indígena: a escrita multimodal kaxinawá. In: SIGNORINI, I. et al. (org.). Investigando a relação oral/ escrito. Campinas: Mercado de Letras 2001. p. 167-192

MIGNOLO. W. What Does It Mean to Decolonize? In: MIGNOLO, W.; WALSH, C. On Decoloniality: Concepts, Analytics, Praxis. Durham and London: Duke University Press, 2018. p. 105-134. DOI: https://doi.org/10.1215/9780822371779007

MIGNOLO, W. Coloniality: The Darker Side of Modernity. In: BREITWIESER, S; KLINGER, C.; MIGNOLO, W. (ed.). Modernologies: Contemporary Artists Researching Modernity and Modernism. Barcelona: MACBA, 2009. p. 39-49.

MIGNOLO, W. El pensamento decolonial: desprendimento y apertura - um manifiesto. In: CASTRO-GOMEZ, S., GROSFOGUEL R. (ed.). El giro descolonial: Reflexiones para una diversidad epistémica más allá del capitalismo global. Bogotá: Siglo del Hombre Editores; Universidad Central, Instituto de Estudios Sociales Contemporáneos y Pontificia Universidad Javeriana, Instituto Pensar, 2007. p. 25-46.

MIGNOLO, W. Local Histories/Global Designs: Coloniality, Subaltern Knowledges, and Border Thinking. Princeton: Princeton University Press, 2000.

MONTE MÓR, W. Learning by Design: Reconstructing Knowledge Processes in Teaching and Learning Practices. In: COPE, B.; KALANTZIS, M. (ed.). A Pedagogy of Multiliteracies. London: Palgrave Macmillan, 2015. p. 186-209. DOI: https://doi. org/10.1057/9781137539724_11

MONTE MOR, W.; DUBOC, A. P.; FERRAZ, D. M. Critical Literacies Made in Brazil. In: PANDYA, J. Z.; MORA, R. A.; ALFORD, J.; GOLDEN, N.; ROOCK, R. (ed.). Critical Literacies Handbook. Routledge. Forthcoming

OSORIO, R. A Desigualdade racial da pobreza no Brasil. Rio de Janeiro: Instituto de Pesquisa Econômica Aplicada - IPEA, 2019 Available at: http:/ / repositorio.ipea. gov.br/bitstream/11058/9336/1/TD_2487.pdf. Access on: 28 Jan. 2021.

PRATT, M. L. Arts of the Contact Zone. In: BARTHOLOMAE, D.; PETROKSKY, A. (ed.). Ways of Reading: An Anthology for Writers. New York: Bedford; St. Martin's, 1999. p. 33-40.

QUIJANO, A. Colonialidade do poder, eurocentrismo e América Latina. In: - A colonialidade do saber eurocentrismo e ciências sociais, perspectivas latinoamericanas. Buenos Aires: CLACSO, 2005. p. 117-142. 
RANCIÉRE, J. The Politics of Aesthetics: The Distribution of the Sensible. London: Continuum, 2005.

RANCIÉRE, J. Disagreement: Politics and Philosophy. Minneapolis: Minnesota University Press, 1999.

REZENDE, T. F. Letramento ontoepistemológico transcultural. 2018. Tese (Pósdoutoramento) - Faculdade de Filosofia e Ciências Humanas, USP, São Paulo, 2018.

SANTOS, B. S. Para além do pensamento abissal: das linhas globais a uma ecologia de saberes. Revista Crítica de Ciências Sociais, Coimbra, v. 78, p. 3-46, 2007. DOI: https://doi.org/10.4000/rccs. 753

STREET, B. Social Literacies: Critical Approaches to Literacy in Development, Ethnography and Education. London; New York: Longman, 1995.

STREET, B. Literacy in the Theory and Practice. Cambridge: Cambridge University Press, 1984.

THE NEW LONDON GROUP. A Pedagogy of Multiliteracies: Designing Social Futures. In: COPE, B.; KALANTZIS, M. (ed.). Multiliteracies: Literacy Learning and the Design of Social Futures. London: Routledge, 2000. p. 9-37.

TOLEDO, L. F. 42\% dos candidatos do ENEN não têm computador em casa. CNN, São Paulo, 14 maio 2020. Available at: https://www.cnnbrasil.com.br/ nacional/2020/05/14/42-dos-candidatos-do-enem-nao-tem-computador-em-casa VEronelLI, G. A. Coalitional Approach to Theorizing Decolonial Communication. Hypatia, [S.l.], v. 31, n. 2, p. 404-420, 2016. DOI: https://doi. org/10.1111/hypa.12238

VERONELLI, G. The Coloniality of Language: Race, Expressivity, Power, and the Darker Side of Modernity. Wagadu, [S.l.], v. 13, p.108-134, 2015.

WALSH, C. Interculturalidad y (de)colonialidad: perspectivas críticas y políticas. Visão Global, Joaçaba, v. 15, n. 1-2, p. 61-74, 2012.

WINDLE, J.; SILVA, F. M.; MORAES, J:; CABRAL, S. A produção de conhecimento teórico no "sul" global: repensando a pedagogia de multiletramentos. In: TAKAKI, N.; MONTE MÓR, W. (org.). Construções de sentido e letramento digital crítico na área de linguas/linguagens. Campinas: Pontes, 2017. p. 101-117.

Data de submissão: 2/2/2021. Data de aprovação: 16/2/2021. 